\title{
The Role of Allelopathy in Pest Management and Crop Production - A Review
}

\author{
Tamirat Wato \\ College of Agriculture and Natural Resource, Department of Plant Sciences, University of Bonga, \\ P.O. Box 334, Bonga, Ethiopia
}

\begin{abstract}
Allelopathy may be a current ecological advance of interference between organisms that will use for handling unwanted plants, insect pests, and diseases in plants. In many crops, allelopathy are often used resulting crop rotation, victimization cover crops, mulching, crop dyspnoeal and plant extracts for ordinary insect pest management. Plant pathogens together with fungi, bacteria, viruses, and nematodes are responsible for great yield losses in several economically vital crops. Use of artificial agrochemicals as soil covering, foliar spray or seed dressing is that the preferred approach for the management of crop diseases in recent days. However, due to the adverse effects of those chemicals on health and environment, customers are presently tightened turn out, that is freed from these chemicals. Natural compounds derived from plants are a lot of environmentally safe than artificial chemicals. Several recent studies have shown that allelochemicals will effectively be used for the management of various plant pathogens. Allelopathy so offers a lovely environmentally friendly different to pesticides in agricultural pest management. Their biopotency is often increased by structural changes or the synthesis of chemical analogs supported them. Though the progress during this regard is slow, even so some promising results are returning and a lot of are expected within the future. This review makes an attempt to discuss these characteristics of allelopathy for the justifiable management of pests.
\end{abstract}

Keywords: allelopathy; role of allelopathy; weed and pest management; and crop production

DOI: $10.7176 /$ FSQM/93-02

Publication date: January $31^{\text {st }} 2020$

\section{Introduction}

Allelopathy can be a comparatively recent and potential space of examination. Allelopathy could be a development whereby secondary metabolites produced by fungi, viruses, microorganisms, and plants influence biological and agricultural systems, which can be either stimulatory or restrictive (Torres et al., 1996; Amb and Ahluwalia, 2016). The word allelopathy comes from two Greek words: 'allelon', which means 'of each other', and 'pathos', which means 'to suffer'. This ancient conception was renowned to classical researchers within the Greek and Roman eras (Wills, 2007). The term 'allelopathy' was initially utilized by Austrian plant physiologist Molísch, who outlined it because of the chemical interaction among plants and microorganisms (Molísch, 1937; Narwal and Jain, 1993).

Allelopathy comprises the production of plant bioactive compounds, called allelochemicals, capable of acting as natural pesticides and might resolve issues like resistance development in pest biotypes, health defects, and soil and environmental pollution caused by the indiscriminate use of artificial agrochemicals (Amb and Ahluwalia, 2016). Allelopathic crops, once used as cover crops, mulch, smother crops, intercrops or inexperienced manures, or fully grown in motility sequences, will combat organic phenomenon stresses like weed infestation, insect pests, and unwellness pathogens and to boot build up fertility and organic matter standing of soil, thereby reducing wearing, and improve farm yields (Dayan et al., 2009).

Sustainable agriculture aims at the long-run maintenance of natural resources and agricultural productivity with stripped-down adverse impacts on the environments (Narwal and Haouala, 2013). It emphasizes ideal crop production with stripped-down external inputs, reducing dependence on business inputs (fertilizer and pesticides) and work them with internal resources and looking forward to sustainable practices, that may uphold the productivity over long periods. Analysis has shown that allelopathic practices might meet these requirements; allelopathy, being a very important development in agriculture, is additionally energetic in property agriculture. Therefore, for the property, upcoming weed management strategy should lessen the application of herbicides and use allelopathic approaches and alternative practices for weed management (Farooq et al., 2011; Narwal and Haouala, 2013).

Unselective practice of herbicides for weed management over the last fifty years has resulted in serious ecological and environmental issues as under; (A) Increasing incidence of resistance in weeds to big herbicides (Duke et al., 2001), (B) Shifts in weed population to species that are additional closely associated with the crops plagued e.g., wild oat grass (Avena fatua) in oat (A. sativa), (C) larger environmental pollution and health hazards (FAO, 1990), (D) Noxious residues of herbicides contaminate the atmosphere and should prove risky to even future generations, (E) Some agricultural commodities might contain minute quantities of weed killer residues, with long adverse effects on human and livestock health (Narwal and Haouala, 2013). Due to the above reasons, serious ecological inquiries on the dependence on herbicides for weed management are raised. FAO 
knowledgeable consultation cluster on 'Weed Ecology and Management 'has expressed nice concern concerning the issues related to the use of herbicides for weed management and has counseled minimizing (Narwal and Haouala, 2013). Or eliminating the use of herbicides with different methods viz., allelopathy to keep up weeds at economic strength and use of fresh crop seed, etc.

Allelopathy might play a crucial role in aiding weed management via restriction of growth of seed plant and its germination. Current consideration of the plant chemical science, physiology, morphology, place down and intra-plant specific interactions and chemistry of natural products have shown that smothering crops, trap crops, and allelochemicals may be employed in weed management, overcoming the problems associated with herbicides (Khanh et al., 2013). Reinhardt et al., (1993) has suggested three allelopathic ways for weed management. These are: (a) selection of weed smothering crops and breeding their varieties to control major weeds throughout a given (Narwal and Haouala, 2013) area, (b) inclusion of allelopathic crops in rotation and/or use their residues as mulches (Liebman and Dyck, 1993), and (c) selecting allelochemicals from plants or microbes with herbicidal activity (Šarić et al. 2011; Zahid et al., 2013).

Perceptive management of allelopathy in planting systems is additionally associate in nursing value effective and accepted methodology of pest management and a replace for weighty use of pesticides. chemical use is additionally reduced by exploiting allelopathy as an alternative pest management tool in property intensive crop production. Several researchers have delineated allelochemicals as natural pesticides. Allelochemicals generally have a mode of action all completely different from artificial herbicides, being further merely and quickly degradable due to a shorter half-life, with relatively fewer group substituents and no unnatural ring structures (Dayan et al., 2009; Kaliyadasa and Jayasinghe, 2018).

Phytochemicals have low or no toxicity to animals and useful insects, possess an array of activity with variable and various sites of action and have a relatively high degradation rate (Regnault et al., 2004; Kaliyadasa and Jayasinghe, 2018). Allelochemicals could influence very important physiological processes like respiration, chemical action, biological process and elongation, membrane liquidness, macromolecule biogenesis and activity of the many enzymes, and should additionally have an effect on tissue water standing (Cloyd, 2004; Papadopoulos et al., 2007).

Allelochemicals are sometimes more effective in mixtures than severally to influence targets. Many research works on allelopathy embraces analysis on allelopathic potential of plants genetic variations among cultivars to overpower crops and weeds, identification of allelochemicals, the status of allelopathy in ecosystems and therefore the prospects of exploitation allelopathic crops for weed management in field crops. Currently, in this review, the potential use of allelopathy as an alternative to pesticides for managing weeds, insect pests, and diseases, particularly in small-farm intensive agricultural systems (Weston and Duke, 2003; Kaliyadasa and Jayasinghe, 2018). Therefore, the most objective of this review paper was to assess the role of allelopathy in pest management and crop production.

\section{Role of Allelopathy in Weed Management for Sustainable Agriculture}

The word weed means that any wild plants that grow at an unwanted place for case in fields and interferes with the enlargement of cultivated plants are famous to scale back crop yield. In agro-ecosystems, weeds contend with crop plants for resources, interfere in crop handling, cut back crop yield and deteriorate their quality, and therefore end in large financial losses (Kholi et al., 2004; Cheng and Cheng, 2015). Various ways (e.g. mechanical and chemicals) are used for weed management. Nowadays, the chemical technique provides an efficient approach for weed management. Not withstanding, the indiscriminate use of herbicides has aggravated an increasing incidence of resistance in weeds to some herbicides, changes in weed population to species additional associated with the crop, environmental pollution, and potential health hazards (Macías et al., 2006; Cheng and Cheng, 2015).

The overuse of artificial chemicals for weed management worsens the standard of soil, water, different life support systems, human health, and food. Because of these issues, energies are being created to go looking out various low-input methods for weed management. During this regard, abundant attention has been centered on the use of allelopathic crop plants and their product for managing weeds during a property manner. Natural product unhitch from allelopathic plants may facilitate to chop back the use of manufactured herbicides for weed management and therefore, cause less pollution, safer agricultural products additionally as alleviating human health issues (Khanh et al., 2007; Sodaeizadeh and Zahra Hosseini, 2012). So, it's worthy to explore the potential of plants with vigorous allelopathic activity for the supervision of agricultural weeds (Sodaeizadeh et al., 2010; Cheng and Cheng, 2015).

According to Weston (2005), the use of allelopathy for dominant weeds might be either through directly utilizing natural allelopathic interactions, notably of crop plants or by exploitation allelochemicals as natural herbicides (Singh et al., 2003; Zahid et al., 2013). Within the former case, a variety of crop plants with allelopathic potential will be used as cowl and manure crops for managing weeds by creating the specified manipulation since the cultural practices and cropping patterns (Singh et al., 2003). These will be befittingly revolved or intercropped with main crops to manage the target weeds (including parasitic ones) by selection. Even the crop mulch/residues 
also can provide fascinating edges (Khanh et al., 2007).

Table 1. Allelopathic inhibition of weeds with various mulches, crop residues, and cover crops

\begin{tabular}{cccc}
\hline Allelopathic source & Application mode & Dominant weed species & $\begin{array}{c}\text { Weed control } \\
\text { (over control) }\end{array}$ \\
\hline Black mustard & Mulch & Avena fatua $\mathrm{L}$ & $68 \%$ reduction in DW \\
Billy goat weeds & Mixed in the soil as powder & Echinochloacrus-galli $\mathrm{L}$. & $70 \%$ reduction in growth \\
Rye & Cover crop & Amaranthus spp. & $80-90 \%$ reduction growth \\
White tephrosia & Mulch & Phalaris minor Retz. & $81.1 \%$ reduction in density \\
\hline
\end{tabular}

Source: (Singh et al., 2003; Batish et al., 2007).

\subsection{Allelopathy as Crop Rotation}

Crop rotation is that the consecutive sowing of varied crops in an exceedingly specific field over an explicit period. In crop rotation, allelopathic or dyspnoeal crops use allelochemicals exuded by roots and free by the decomposition of preceding crop residues to suppress weeds, sickness pathogens and bug pests (Voll et al., 2004). A properly designed crop rotation will increase yield by around two hundredths. Crop rotation results in various advantages over monocultures. The charge had advanced to pest management once developing the rotation. Factors like totally different root systems and plant design, variations in sowing and gathering times, allelopathy, variable soil, and crop management techniques and numerous cultural practices are also liable for cuss suppression and different advantages in an exceeding rotation (Peters et al., 2003).

Plant-released allelochemicals through root exudation and litter decomposition in movement sequence suppress weeds. Crop rotation is additionally useful in neutralizing potential automotive vehicle cytotoxic effects related to allelochemicals. Crops following sorghum (Sorghum bichrome L.) faceless weed competition attributable to suppression of weeds by allelochemicals more to the soil by the sorghum crop (Einhellig and Rasmussen, 1989; Alhameid et al., 2017). Rice - wheat could be a major cropping system in several Asian countries (Farooq et al., 2011). Heavily troubled with weeds, this technique, for the most part, depends on weed killer inputs for weed management. Integration of dyspnoeal allelopathic crops like cereal (Pennisetum glaucum L.), maize and sorghum within the rice-wheat cropping system, grown once gathering wheat (Triticum aestivum L.) and before rice transplantation, offers effective weed management for the approaching rice crop for a minimum of forty-five days (Peters et al., 2003; Alhameid et al., 2017). Wheat has the potential for integration as a trap crop because it stimulates parasitic seed germination while not attachment, thus operating as a false host. This can, therefore, be used to suppress the parasitic weed infestation (Lins et al., 2006; Alhameid et al., 2017).

\subsection{Allelopathy as Cover crops}

Cover crops are grown to control weeds, conserve soil, suppress insects, nematodes and different illness pathogens, enhance nutrient utilization and provide fodder (Jabran et al., 2018). Necessary cover crops embody sun hemp (Crotalaria juncea L.), yellow sweet clover (Melilotus officinalis L.), sorghum, cowpea, alfalfa (Medicago sativa L.), Bengal bean, red clover, and rye grass (Lolium perenne L.) (L. Edwards 2005; Jabran et al., 2018). Legume crops like Bengal bean, Jumbie bean (Leucaena leucocephala L.), wild tamarind (Lysiloma latisili-quum L.) and jack bean (Canavalia ensiformis. L.), used as cover crops in maize, likewise, barley (Hordeum vulgare L.) adult as a canopy crop for weed management in soybean suppressed weeds like grass (Digitaria ciliaris L.) and barnyard grass (Kobayashi et al., 2003).

Cover crops incorporated into the soil as manure will delay planting and emergence attributable to excess soil wet, have phytotoxic effects on major crops and increase element immobilization (Michel A. et al., 2012). This can, however, is avoided through the adoption of excellent management practices and by optimizing and desegregation cowl crops in a very cropping system (Caporali et al., 2004; Jabran et al., 2018).

\subsection{Allelopathy as Mulching}

Mulches are plant materials such as straw of the previous crops that are used as a soil cover mainly for conservation of soil moisture (Acharya et al., 2005; Ambayeba, 2018). Mulches hinder seed germination of weeds and stop weed seed plant growth through the discharge of allelochemicals established weeds, however, are tough to regulate with mulches (Saha et al., 2018). Additionally, to weed suppression, use of allelopathic crop residues as surface mulch advantages agricultural property by adding organic interest soil, protective soil wet, up water infiltration into soil, decreasing the impact of raindrops on soil, modifying/regulating soil temperature, enhancing biological activities in soil and dominant wearing away (Teasdale and Mohler, 2000; Kasirajan and Ngouajio. 2012; Stauffer and Spuhler, 2019).

Allelopathic plant mulches applied to rice fields at suppressed degrading paddy weeds like barn grass, purple loony edge (Cyperus rotundus L.), and wheat residues as soil cowl reduced weed density and dry weight whereas protective soil wet (Teasdale and Mohler, 2000; Kasirajan and Ngouajio, 2012). According to quantitative relationships between emergence and mulch properties with mulches like maize stalks, rye (Secale cereale L.), 
Italian clover (T. incarnatum L.), hairy tare (Vicia villosa Roth), genus Quercus leaves and landscape cloth strips (Ambayeba, 2018; Stauffer and Spuhler, 2019).

\subsection{Allelochemicals as Herbicides}

There is increasing resistant that allelochemicals or natural plant products derived from higher plants/microbes will be ideal agrochemicals (Kohli et al., 1999). Originally, the description of why plants devote resources to the assembly of those compounds was not understood as they were considered functionless waste products. It is currently progressively accepted, however, that these compounds operate as defensive agents against pathogens, insects and neighboring plants (Mattner, 2006).

Many such natural compounds have the potential to induce a good array of biological effects and may offer nice advantages to agriculture and weed management (Macías et al., 2006). There are varied confirmation bestowed that higher plants unleash a range of allelochemicals into the encircling. many factors verify their toxicity like concentration, flux rate, age and metabolic state of the plant, and prevailing environmental conditions and environmental conditions (Singh et al., 1999). Einhellig (1996) mentioned that each abiotic (temperature, nutrient quantity, and wetness deficit) and organic phenomenon (disease and bug harm and interaction of plans with herbivory) factors increase the number and biogenesis of allelochemicals in plants (Sodaeizadeh et al., 2012).

\subsection{Allelopathy for the Management of Phytopathogens}

Crop plants are attacked by an outsized variety of pathogens particularly fungi, bacteria, viruses, phytoplasmas, and nematodes. These pathogens are to blame for substantial plant growth and yield losses. For a lot of property systems, there's an associate increasing trend towards exploring natural and environmentally friendly alternatives to those chemicals (Cuthbertson and Murchie, 2005).

Exploiting the allelopathic potential of plants is one in every of the foremost in style different ways to manage the phytopathogens (FAO, 2003; Farooq et al., 2011). Many plant species are capable of manufacturing and releasing biologically active compounds referred to as allelochemicals. These compounds are free into the surroundings by numerous mechanisms as well as root exudation, activity from aerial elements particularly leaves, volatile emissions and decomposition of material (Xuan et al., 2005). In step with the International Allelopathy Society, allelopathy issues the study of any method involving secondary metabolites created by plants, algae, bacteria, and fungi that influence the expansion and development of agricultural and biological systems (IAS, 1996; FAO, 2003; Macias et al., 2007). The harmful impact of allelopathy may be exploited for the management of pests and diseases (Kohli et al., 1998; FAO, 2003). The development of allelopathy has recently received larger attention from researchers and farmers worldwide (Farooq et al., 2011).

\subsubsection{Management of Fungal Pathogens}

About seventy-five you look after plant diseases square measure caused by fungi. On the idea of morphology and biology, there are several infamous plant pathogens like Macrophomina phaseolina, Sclerotium rolfsii, Fusarium solani, F. oxysporum and plenty of different that cause diseases on an oversized variety of host plants. M. phaseolina may be a soil-borne plant infective agent that causes charcoal rot sickness in additional than five hundred completely different monocotyledonous and dicotyledonous plant species together with such necessary crops as sorghum, soybean, alfalfa, maize (Wyllie, 1993). So far, there is no registered antifungal against the charcoal rot infective agent. Similarly, S. rolfsii is additionally a soil-borne plant infective agent answerable for vital economic losses on a large vary of science host plants together with five hundred plant species, in over a hundred plant families, in countries of Asia, Australia, Africa, America, and Europe.

Plant diseases caused by fungi embody leaf spots, root and crown rot, rust, smut, blight, wilt, dieback, mildew, mildew, etc. Triazole derivatives like diniconazole, triadimefon, tebuconazole, and hexaconazole represent the foremost necessary class of fungicides thus far, effective against a large spectrum of crop diseases (Lu et al., 2011).

\subsubsection{Management of Bacterial Pathogens}

Plant pathogenic microorganism causes many serious diseases of plants over the world (Vidaver and Lambrecht, 2004; Derib et al., 2013). However, microorganism diseases are fewer than fungi or viruses and that they cause comparatively less injury and economic loss (Kennedy and Alcorn, 1980; Derib et al., 2013). There are two hundred microorganism species inflicting severe economically damaging diseases worldwide on one hundred fifty plant genera belonging to quite fifty families of upper plants. The bulk of plant-associated microorganisms are rods, symptoms of microorganism diseases on plants starting from spots, mosaic patterns or pustules on leaves and fruits, or malodourous tuber rots to plant death (Derib et al., 2013; Thiele et al., 2012).

There are several examples of exploiting the allelopathic potential of the plants for the management of microorganism plant pathogens and diseases. Intercropping of garlic (A. tuberosum) with tomato considerably delayed and suppressed the prevalence of microorganism wilt of tomato caused by Pseudomonas solanacearum Smith while not having any negative impact on the tomato. spread from varied elements of dicot genus mukorossi, tree nilotica, Phyllanthus emblica and Terminalia chebula was extremely restrictive against bacteria genus campestrispv. citri and reduced the number of lesions on detached leaves and fruits. Volatile plant oil thyme 
camphor (2-isopropyl-5-methylphenol) application considerably reduced Ralstonia solanacearum wilt incidence and exaggerated the yield of tomato beneath field conditions binary compound extracts of contemporary leaves of datura stramonium, A. Sativum and oleander exhibited antibacterial activity against microorganism wilt microorganism Ralstonia solanacearumin vitro and in vivo (Abo-Elyousr and Asran, 2009; Derib et al., 2013).

\subsubsection{Management of Plant Nematodes}

Nematodes are tiny wormy cellular organisms and customarily live freely within the soil. Many nematode species are parasitizes plant roots and is problematic in tropical and semi-tropical regions of the World (CN, 2017). Plantparasitic nematodes scale back productivity and general suitability of the plants by feeding plant nutrients. There are concerning 1, 200 plant-parasitic nematode species responsible for influential economic losses to an excellent vary of hosts (Derib et al., 2013). Vegetable and agronomical crops, fruit, nut and forest trees, and turfgrass square measure attacked by nematodes. Typical root symptoms embody knots or galls, root-lesions, extreme root branching, lac root tips, and lower root systems. The foremost damaging are root-knot nematodes (Meloidogyne spp.) that have quite a massive host vary (Douda et al., 2012; CN, 2017).

Global economic losses caused by Meloidogyne sp. nematodes were evaluated at a hundred billion USD annually (CN, 2017). Soil fumigants particularly bromide, methyl radical halide, propargyl bromide or 1, 3dichloro propylene square measure recommended for nematode management but, several of those chemicals disturb soil ecosystems (CN, 2017). Different physical strategies as well as steam medical aid, soil exposure, and plight injection have conjointly been utilized for the management of nematode with variable success as alternate to soil coating with artificial chemicals. However, several factors, as well as soil sort, atmospheric condition and water content of the soil, will have an effect on the effectiveness of physical treatments (Wang et al., 2009; CN, 2017).

\subsubsection{Allelopathy for Insect-Pest Control}

Extensive use of artificial pesticides sometimes has negative effects on the atmosphere and on human and animal health and, most critically, develops resistance among insects. Scientists are so turning towards natural insect suppressants. Neem (Azadirachta indica L.) seed oil exhibits antifeedant properties against nymphs and adults of strawberry aphids (Chaetosiphon fragaefolii (Cockerell)) (Lowery et al., 1993; Farooq et al., 2011), Conifer plantations treated with neem oil deter feeding activity of large pine weevil (Hylobius abietis L.) for 3 months (Farooq et al., 2011). Sitka spruce [Picea sitchensis (Bong.)] seedlings without neem oil treatment were killed by the feeding weevil, while those treated with neem oil (30 cm above the root collar) were not affected; azadirachtin, nimbin and salannin are the allelochemicals identified in neem oil (Thacker et al., 2003; Farooq et al., 2011).

Decomposing residues of canopy crops improved soil nutrient standing and free allelochemicals that deter plant pests, significantly soil-borne unwellness pathogens (Gallandt and Haramoto, 2004; Farooq et al., 2011). Exposure to volatile oils from eucalyptus (Eucalyptus globulus L.) throughout larval periods of rice lepidopteran (Corcyra cephalonica St) severely affected post-embryonic development and adult emergence evaluated the effectiveness of allelopathic water extracts of sorghum, mustard, and helianthus, alongside combos of sorghum and mulberry (Morus alba L.) and sorghum and helianthus, for dominant aphids and ingestion insects of dilleniid dicot genus spp.

According to Farooq et al., (2011) reported that sorghum water extracts were simplest (62.5\% aphid mortality) at a concentrationa of $8 \%$, and sunflower water extracts (16\% concentration) resulted in $52.5 \%$ aphid mortality. Combination water extracts (16\%) of sorghum and mulberry resulted in $45.7 \%$ aphid mortality, and sorghum and flower had 57.5\% mortality ( Farooq et al., 2011).

Table 2. Allelopathic suppression of insect pests

\begin{tabular}{lll}
\hline \multicolumn{1}{c}{ Allelopathic source } & \multicolumn{1}{c}{ Application rate/mode } & \multicolumn{1}{c}{ Insect suppression } \\
\hline California pepper tree & Ethanol extract $(4.7 \% \mathrm{w} / \mathrm{v})$ & $91.77 \%$ mortality of elm leaf beetle \\
Fig-leaf goosefoot & Ethanol extract $5000 \mathrm{mg} \mathrm{mL}$ & $86 \%$ control of aphid \\
Eucalyptus & Oil volatiles & $78 \%$ of adults of Corcyra cephalonica \\
Birbira & Seed crude extract & $93-100 \%$ of adult Macrotermes termites \\
Neem & Seed kernels water extract (2\%) & thrip (54\%) and pod borer (32\%) incidence \\
Tomato & Leaf Water Extract (2\%) & Reduction in Flowet thrip (12\%) \\
Hot Pepper & Fruit Water Extract (4\%) & Reduction in Flowet thrip (31\%)
\end{tabular}

Source: Hongo H and Karel. 1986; Farooq et al., 2011.

2.5.5. Role of Allelopathy in Disease management

Plant disease could be a serious issue inflicting harmful effects on several crops as well as cereals, oilseeds, etc., and particularly vegetables. A variety of soil-borne diseases cause substantial losses to crop production by distressing the crop stand and lowering product quality. Intercropping creates a microclimate, that is useful for reducing unwellness intensity (Gómez et al., (2003). Japanese cedar (Cryptomeria japonica L) bark has repressive effects against diseases inflicting root infections in tomato (Lycopersicon esculentum L.) (Derib et al., 2013). Root exudates from garlic (Allium tuberosum L.) inhibit the multiplication of microorganism's wilt (Pseudomonas solanacearum Smith). Bound volatile allelochemicals are exuded from aerial components of Sunflower (Tagetes 
erecta L.) microorganism wilt of tomato (Ps. solanacearum) has been well controlled by intercropping tomato with cowpea. Brassica spp. produces volatile sulfur compounds (glucosinolates) within the soil microenvironment, that are regenerate to isothiocyanates through bio-fumigation to suppress soil organisms. These compounds will scale back plant pathogens and nematodes within the soil (Cohen et al., 2005; Farooq et al., 2011)

Table 3. Allelopathic suppression of pathogens, nematodes, and diseases

\begin{tabular}{|c|c|c|c|}
\hline $\begin{array}{l}\text { Allelopathic } \\
\text { source }\end{array}$ & $\begin{array}{l}\text { Application } \\
\text { mode/rate }\end{array}$ & Pathogen/disease suppression & Reference \\
\hline Barley + potato & Grown in rotation & $\begin{array}{l}55.1 \% \text { reduction in inoculum intensity } \\
\text { of Rhizoctonia solani (JG Kühn) }\end{array}$ & $\begin{array}{l}\text { Larkin and Griffin } \\
(2007)\end{array}$ \\
\hline Turnip + Potato & Grown in rotation & $\begin{array}{l}56.2 \% \text { reduction in inoculum intensity } \\
\text { of Rhizoctonia solani (JG Kühn) }\end{array}$ & \\
\hline $\begin{array}{l}\text { Indian Mustard + } \\
\text { potato }\end{array}$ & Grown in rotation & $\begin{array}{l}45.5 \% \text { reduction in inoculum intensity } \\
\text { of Rhizoctonia solani (JG Kühn) }\end{array}$ & \\
\hline Rice & $\begin{array}{l}\text { Root exudates (1.5 } \\
\mathrm{mL})\end{array}$ & $\begin{array}{l}37 \% \text { reduction in germination of } \\
\begin{array}{l}\text { Fusarium oxysporum f. sp. Niveum } \\
\text { spores }\end{array}\end{array}$ & Ren et al.,(2008) \\
\hline Rice & $\begin{array}{l}\text { Root exudates }(20 \\
\mathrm{mL})\end{array}$ & $\begin{array}{l}71.88 \% \text { reduction in spore reproduction } \\
\text { of Fusarium oxysporum f. sp. Niveum } \\
\text { spores }\end{array}$ & \\
\hline Neem & $\begin{array}{l}\text { Leaf water extract } \\
(20 \% \mathrm{w} / \mathrm{v})\end{array}$ & $\begin{array}{l}53.22 \% \quad \text { Fusarium solani } \text { f. } \quad \text { sp. } \\
\text { Melongenae }\end{array}$ & Joseph et al., (2008) \\
\hline Eucalyptus & $\begin{array}{l}\text { Leaf water extract } \\
(20 \% \mathrm{w} / \mathrm{v})\end{array}$ & $\begin{array}{l}46.76 \% \text { Fusarium solani } \\
\text { Melongenae }\end{array}$ & \\
\hline Neem & cake $3 \%(\mathrm{w} / \mathrm{w})$ & $\begin{array}{l}63.7 \% \text { in root-knot nematode egg } \\
\text { masses per root }\end{array}$ & Javed et al., (2007) \\
\hline
\end{tabular}

Source: Farooq et al., 2011

\subsubsection{Limitation of Using Allelopathic Effects}

There are several limitations in persecuting allelopathic potentiality as a pest management tool. The restrictions are each due to the plant itself, synthesizing allelochemical and also the status. Several abiotic and organic phenomenon of soil factors have influences on phototoxic levels of allelochemicals (Huang et al., 1999; Inderjit et al., 1999). Many nonliving and organic compounds factors like plant age, temperature, light-weight and soil condition, microflora, and nutritionary standing and herbicides actions affects the meeting and unharness of the allelochemicals through allelopathy is taken into account as a genetically influenced issue (Put nam 1985).

While acquiring the soil allelochemicals could bear a change as varied factors concerning soil surroundings like physical, chemical, and physicochemical properties of soil could influence the activity of allelochemicals. Thus, to review the allelopathic potential of plants the role of soil should not be ignored in keeping with (Inderjit and Dakshini, 1984; Robert and Zimdahl, 2018). The number of nutrients accessible to plant and also the potency of the plant to utilize the nutrient influences the allelopathic potentiality of the rice plant, mainly the deficit of the soil nutrient favors the assembly of secondary metabolites as mentioned by (Xuan, et al., 2005; Joao and Yunes, 2019). There should be some color force among machine cyanogenic chemicals and environments (Bhuleret et al., 1998; Robert and Zimdahl, 2018).

\section{Summary and Conclusion}

Allelochemicals are proficient of representing as natural pesticides and should resolve issues like resistance development in pest biotypes, health defects and soil and environmental pollution caused by the indiscriminate use of artificial agrochemicals. Allelopathic crops, once used as cowl crops, mulch, intercrops or inexperienced manures, or grown in movement sequences, will combat natural phenomenon stresses like weed infestation, insect pests, and illness pathogens and else build up fertility and organic matter standing of soil, thereby reducing eroding, and improve farm products. Allelopathic implication of some higher plants could also be exploited for the management of a many of phytopathogens mainly fungi, bacteria, and nematodes. Moreover, allelopathic crops could also be incorporated to the soil as manure to decrease the numbers of phytopathogens. These natural productbased pesticides can apparently be system less harmful to the atmosphere as compared to manufactured agrochemicals. Allelochemicals are concerned as biodegradable; having totally different modes of action and weed would not simply develop resistance to them. However, there are several limitations of victimization allelopathic probably as a weed management tool. The restrictions are of extent individually as a consequences of the plant itself, producing allelochemicals and environmental conditions. Increasing attention has been assumed to the role and potential of allelopathy as a management strategy for crop protection against pests.

Incorporating allelopathy into natural and organic management practices might reduce the application of herbicide, insecticides, and different pesticides, reducing environment and edaphic contamination as well as 
reducing autotoxicity hazards. There is an exquisite demand for compounds with selective toxicity which can be promptly degraded by either the plant or by the soil microorganisms. Moreover, totally all plant species, microorganisms, alternative soil organisms, and insects will end up allelochemicals that deliver new approaches for upholding and enhancing agricultural production and productivity within the longer term.

\section{Prospects}

Plant allelopathy plays a great role in pest managements and agricultural systems of crop production. It can cause effects in all biotic organisms through affecting environmental pollution, unsafe agricultural products, human health issues, and decline in crop productivity, soil illness and depletion of crop diversity could also be treated fitly if crop allelopathy is fitly utilized or manipulated. Allelopathic crops ought to be used as cowl crops, smother crops, companion crops, and crop rotation. The choice of crop varieties with robust allelopathic potential to biologically scale back the intensity of pests, weeds, pathogens, diseases, and nematodes is indispensable inside the present and future agricultural production.

Several roles of allelopathy have already been done and a few studies are ongoing though some areas are required to be studied extensively to implicate the mechanism of allelopathy with success. For best use of allelopathy below field conditions, the influence of environmental factors has to be investigated. During this concern, soil setting is that the most significant issue. So, this space desires special attention to form allelopathic potentiality prosperous. The use of serious doses of herbicides creates a matter of resistance development in weed. Furthermore, the regular use of a single chemical will amend the weed community and used for effective use of allelopathic characters the distinctive character of allelochemicals are important. It should happen that quite one allelochemicals are concerned with allelopathic mechanisms. So, the finding of genes coding for allelopathy in various plants is needed.

\section{References}

A. Alhameid, T. Schumacher. (2017). Intensified Agroecosystems and Changes in Soil Carbon Dynamics, in Soil Health and Intensification of Agroecosytems.

Abo-Elyousr KAM, Asran MR. (2009). Antibacterial activity of certain plant extracts against bacterial wilt of tomato. Arch Phytopathol Plant Prot 42:573-578.

Ambayeba Muimba-Kankolongo. (2018). Food Crop Production by Smallholder Farmers in Southern Africa. Challenges and Opportunities for Improvement. https://doi.org/10.1016/B978-0-12-814383-4.00007-4

Anaya, Ana Luisa. (2006). Allelopathic Organisms and Molecules: Promising Bioregulators for the Control of Plant Diseases, Weeds, and Other Pests. 10.1007/1-4020-4447-X_3.

B. Stauffer and D. Spuhler. (2019). Soil Solarization: A Non pesticidal Method for Controlling Diseases, Nematodes, and Weeds.

Batish DR, Arora K, Singh HP, and Kohli RK. (2007). Potential utilization of dried powder of targets minuta as a natural herbicide for managing rice weeds. Crop Prot 26: 566-571.

Batish, D. R., H. P. Singh, R.K.Kohli, and.Kaur (2001). Crop allelopathy and its role in ecological Agriculture. $J$. Crop Prod. 4, 121-162.

C.L. Acharya, K.K. Bandyopadhyay. (2005). MULCHES. in Encyclopedia of Soils in the Environment.

Crop Nuts (CN). 2017. Understanding your nematode analysis report. Plant Parastic Nematode (PPN) Fact Sheet.

Cuthbertson AGS, Murchie AK. (2005). Economic spray thresholds in need of revision in Northern Irish Bramley orchards. Biol News 32:19.

Derib Alemu, Fikre Lemessa, Mulatu Wakjira and Gezahegn Berecha, 2013. Antibacterial Activity of Some Invasive Alien Species Extracts Against Tomato (Lycopersicon esculentum Mill) Bacterial Wilt Caused by Ralstonia solanacearum (Smith). Plant Pathology Journal, 12: 61-70. DOI: 10.3923/ppj.2013.61.70

Douda O, Zouhar M, Nováková E, Mazáková J. (2012). Alternative methods of carrot (Daucus carota) protection against the northern root-knot nematode (Meloidogyne hapla). Acta Agricultural Scandinavica, Section B. Soil Plant Sci 62:91-93

Duke SO, Dayan FR, Romaine JG, Rimando AM. (2000). Natural products as sources of herbicides: status and future trends. Weed Res 40:99-111.

Einhellig, F. A, (1996). Interactions involving allelopathy in cropping systems. Agron. J, 88: p 886-893.

F. Cheng and Z. Cheng. (2015). Research Progress on the use of Plant Allelopathy in Agriculture and the Physiological and Ecological Mechanisms of Allelopathy. https://doi.org/10.3389/fpls.2015.01020

FAO (Food and Agricultural Organization) (1990). Proceedings of FAO International Conference on Weed Control. University of California, Davis.

FAO (Food and Agricultural Organization) (1997). Expert consultation group meeting on weed ecology and management, Rome.

Farooq, Muhammad \& Jabran, Khawar and Cheema, Zahid and Wahid, Abdul and Siddique, Kadambot. (2011). The role of allelopathy in agricultural pest management. Pest management science. 67. 493-506. 
10.1002/ps.2091.

Food and Agriculture Organization of the United Nations (FAO). (2003). Weed Management for Developing Countries.

Francisco A Macias, Jose MG Molinillo, Rosa M Verela and Juan CG Galiindro (2007). Allelopathy-a natural alternative for weed control. https://doi.org/10.1002/ps.1342

Fukuta M, Xuan TD, Deba F, Tawata S, Khanh TD, Chung IM. (2007). Comparative efficacies in vitro of antibacterial, fungicidal, antioxidant, and herbicidal activities of momilatones A and B. J Plant Interact $2: 245-251$.

H. P. Singh, Daizy R. Batish and R.K. Kohli (2003). Allelopathic Interactions and Allelochemicals: New Possibilities for Sustainable Weed Management, Critical Reviews in Plant Sciences, 22:3-4, 239-311, DOI: $10.1080 / 713610858$

H. Sodaeizadeh, Z. Hosseini (2012). Allelopathy an Environmentally Friendly Method for Weed Control. International Conference on Applied Life Sciences (ICALS2012)

Hongo H. and Karel AK, (1986). Effect of plant extracts on insect pests of common beans. J Appl Entomol 102: $164-169$

IAS (International Allelopathy Society) (1996). Constitution and Bylaws. http://www-ias.uca.es/ By laws.htm.

Javed N, Gowen SR, Inam-ul-Haq M, Abdullah K and Shahina F, (2007). Systemic and persistent effect of neem (Azadirachta indica) formulations against root-knot nematodes, Meloidogyne javanica, and their storage life. Crop Prot 26:911-916.

Joao Sarkis Yunes. (2019). Cyanobacterial Toxins in in Cyanobacteria.

Joseph B, Dar MA and Kumar V, (2008). Bioefficacy of plant extracts to control Fusarium solani f. sp. melongenae incitant of brinjal wilt. Global J Biotech Biochem 3:56-59.

K. Jabran, N. Tursum, D. Isik, and Z. Demir. (2018). Use of Living, Mowed, and Soil-Incorporated Cover Crops for Weed Control in Apricot Orchards. Agronomy, 8(8), 150; https://doi.org/10.3390/agronomy8080150

Kaliyadasa, E., and Jayasinghe, S. L. (2018). Screening of allelopathic activity of common weed species occurring in agricultural fields. African Journal of Agricultural Research, 13(47), 2708-2715. DOI: https://doi.org/10.5897/AJAR2018.13612

Kennedy BW, and Alcorn SM. (1980). Estimates of U.S. crop losses to prokaryote plant pathogens. Plant Dis 64:674-676.

Khanh, T.D., A.A. Elzaawely, I.M. Chung, J.K. Ahn, S. Tawata, and T.D. Xuan (2007). Role of allelochemical for weed management in rice. Allelopathy Journal, 19: p. 85-96.

Kholi, R.K., H.P. Singh, and D.R. Batish (2004). Allelopathy in agroecosystems. Food Products Press. New York, USA.

Kohli RK, Batish D, Singh HP (1998). Allelopathy and its implications in agroecosystems. J Crop Prod 1:169202.

Kohli, Ravinder \& Batish, Daizy \& Singh, Dr H. (1999). Allelopathy as a tool for weed and pest management. Journal of Punjab Academy of Sciences. 1. 127-131.

L. Edwards, J. Burney. (2005). Cover Crops, in Encyclopedia of Soils in the Environment.

L.A. Weston. (2005). History and Current Trends in the Use of Allelopathy for Weed Management. Hort Technology 15(3). DOI: 10.21273/HORTTECH.15.3.0529

Larkin RP and Griffin TS, (2007). Control of soilborne potato diseases using Brassica green manures. Crop Prot 26:1067-1077.

Liebman M, Dyck E. (1993). Crop rotation and intercropping strategies for weed management. Ecol Appl 3:92122.

Lowery DT and Isman MB, (1993). Antifeedant activity of extracts from neem, Azadirachta indica, to strawberry aphid, Chaetosiphon fragaefolii. J Chem Ecol 19:1761-1773 (1993).

Lu WC, Caoc XF, Hua M, Lia F, Yua GA, Liu SH. (2011). Highly enantioselective access to chiral 1-(bArylalkyl)-1H-1,2,4-triazole derivatives as potential agricultural bactericides. Chem Biodivers 8:1497-1511.

M. K. Amb, A. S. Ahluwalia. (2016). Allelopathy: Potential Role to Achieve New Milestones in Rice Cultivation. Rice Science, 23(4): 165-183. DOI: 10.1016/j.rsci.2016.06.001

Macías, F.A., N. Chinchilla, R.M. Varela, and J.M.G. Molinillo, (2006). Bioactive steroids from Oryza sativa L. Steroids, 71: p. 603-608.

Mattner, S.W. (2006). The impact of pathogens on plant interference and allelopathy In Inderjit, \& Mukerji, K. G., (Eds.). Allelochemicals: Biological control of plant pathogens and diseases. Springer. Dordrecht, the Netherlands.

Michel A. Cavigelli, Timothy B. Parkin. (2012). Cropland Management Contributions to Greenhouse Gas Flux in Managing Agricultural Greenhouse Gases.

Papadopoulos, Apostolos and Alderson, Peter. (2007). A new method for collecting isothiocyanates released from plant residues incorporated in soil. Annals of Applied Biology. 151. 61 - 65. 10.1111/j.1744-7348.2007.00149. 
$\mathrm{X}$.

Paulo ARCJ, and Gouveia PR. (2009). Nozzle and spray volume effects on chemical control of maize diseases. Rev Cienc Agron 40:533-538.

Reinhardt CF, Meissner R, Nel PC. (1993). Allelopathic effect of sweet potato (Ipomoea batatas) cultivars on certain weed and vegetable species. South Afric J Plant Soil 10:41-44.

Ren L, Su S, Yang X, Xu Y, Huang Q and Shen Q, (2008). Intercropping with aerobic rice suppressed Fusarium wilt in watermelon. Soil Biol Biochem 40:834-844.

Rice E.L. (1984). Allelopathy, $2^{\text {nd }}$ eds. Academic Press Inc., Orlando, FL, p 422.

Robbins W, Crafts AS, and Raynor RN. (1982). Weed control. McGraw Hill, New York.

Robert L. and Zimdahl. (2018). Allelopathy in Fundamentals of Weed Science (Fifth Edition).

S. Kasirajan and M. Ngouajio. (2012). Polyethylene and biodegradable mulches for agricultural applications: a review. Agronomy for Sustainable Development; V(32), 501-529

S.S.Narwal and Raabia Haouala, (2013). Role of Allelopathy in Weed Managements for Sustainable Agriculture. Z.A. Cheema et al. (eds.), Allelopathy, DOI: 10.1007/978-3-642-30595-5-10, @ Springer- Verlag Berlin Heidelberg.

Saha D, Marble S.C. and Pearson BJ. (2018). Allelopathic Effects of Common Landscape and Nursery Mulch Materials on Weed Control. Front. Plant Sci. 9:733. doi: 10.3389/fpls.2018.0073

Sing, H. P., Batish, Daizy R., Kohli, R.K. (2003). Allelopathic Interactions and Allelochemicals: New Possibilities for Sustainable Weed Management. Critical Reviews in Plant Sciences, V 22 (3-4). DOI: https://doi.org/10.1080/713610858

Singh, H.P., D.R. Batish, and R.K. Kohli, (1999). Autotoxicity: Concept, Organisms, and Ecological Significance. Critical Reviews in Plant Sciences, 18: p. 257-272.

Sodaeizadeh, H., M. Rafieiolhossaini, and P. Van Damme, (2010). Herbicidal activity of a medicinal plant, Peganum harmala L., and decomposition dynamics of its phytotoxins in the soil. IndustrialCrops and Products: 31: p. 385- 394.

T. Šarić, Z.Ostojić, L. Stefanović, S. D. Milanova, G. Kazinczi, L. Tyšer. (2011). THE Changes of the Composition of Weed Flora in Southeastern and Central Europe as Affected by Cropping Practices: Herbologia Vol 12 (1).

T.D. Khanh, L.H. Linh, T.H. Linh, N.T. Quan, D.M. Cuong, V.T.T. Hien, L.H. Ham and T.D. Xuan. (2013). Integration of Allelopathy to Control Weeds in Rice. DOI: 10.5772/56035

Thacker JRM, Bryan WJ, McGinley C, Heritage S and Strang RHC, (2003). Field and laboratory studies on the effects of neem (Azadirachta indica) oil on the feeding activity of the large pine weevil (Hylobius abietis L.) and implications for pest control in commercial conifer plantations. Crop Prot 22:753-760

Thiele K, Smalla K, and Kropf S. (2012). Detection of Acidovorax valerianellae, the causing agent of bacterial leaf spots in corn salad [Valerianella locusta L.], in corn salad seeds. LettAppl Microbiol 54:112-118.

Vidaver, A.K., and P.A. Lambrecht (2004). Bacteria as plant pathogens. The Plant Health Instructor. DOI: 10.1094/PHI-I-2004-0809-01

Wang HD, Chen JP, and Wang AG. (2009). Studies on the epidemiology and yield losses from rice black-streaked dwarf disease in a recent epidemic in Zhejiang province, China. Plant Pathol 58:815-825.

Wyllie TD. (1993). Charcoal Rot. In: Sinclair JB, Backman PA (eds) Compendium of soybean diseases, 3rd edition. APS Press, St. Paul, pp 30-33.

Xuan TD, Shinkichi T, Khanh TD, and Min CI. (2005). Biological control of weeds and plant pathogens in paddy rice by exploiting plant allelopathy: an overview. Crop Prot 24:197-206.

Z. A. Cheema, M. Farooq, and A. Wahid. (2013). Allelopathy: Current Trends and Future Applications. DOI: 10.10007/978-642-3594-5-8. 